\author{
Justus Gerhard Garweg \\ Christiane Elisabeth Russ \\ Marc Schellhorn \\ Matthias Böhnke \\ Markus Halberstadt
}

\section{HSV-1 antigens and DNA in the corneal explant buttons of patients with non-herpetic or clinically atypical herpetic stromal keratitis}

Received: 10 January 2003

Revised: 9 April 2003

Accepted: 9 April 2003

Published online: 21 June 2003

(C) Springer-Verlag 2003

Commercial interests: none

J. G. Garweg $(\bullet) \cdot$ C. E. Russ

M. Halberstadt

Department of Ophthalmology,

University of Bern, Inselspital,

3010 Bern, Switzerland

e-mail: justus.garweg@insel.ch

Tel.: +41-31-6329565

Fax: +41-31-6328539

C. E. Russ

Private Practice,

Rosengarten, Germany

M. Schellhorn

Department of Ophthalmology,

Städtische Krankenanstalten,

Ludwigshafen, Germany

M. Böhnke

Center for Clinical Ophthalmology,

Hamburg, Germany

\begin{abstract}
Background: Little is known about the role of HSV-1 in keratitis not primarily attributed to herpetic origin. This study therefore aimed to prospectively evaluate the corneal explant buttons of patients with non-herpetic or clinically atypical herpetic stromal keratitis (experimental group: non-HSK) for the presence of $\mathrm{HSV}-1$ antigens and DNA, and to compare the findings with those from individuals with typical herpetic stromal keratitis (positive control group: HSK) or noninflammatory degenerative keratopathy (negative control group). Methods: Corneal buttons derived from 51 patients with HSK, from 72 with non-HSK and from 30 with degenerative keratopathy were prospectively collected and subjected to immunohistochemical analysis for HSV- 1 antigens and to HSV-1 DNA amplification. Results: In corneal buttons derived from patients with non-HSK, viral antigens were detect-
\end{abstract}

ed immunohistochemically in $8 / 72$ cases and DNA amplified in 16/72. Corresponding values for the HSK group were $16 / 51$ and $11 / 51$. Taking viral antigen and DNA findings together, HSV-1 was detected in 18/72 (25\%) patients with non-HSK and in $19 / 51(37 \%)$ with HSK $(p=0.2)$, but in only $2 / 30(6 \%)$ individuals with non-inflammatory degenerative keratopathy. Conclusion: Since the detection frequencies for HSV-1 antigens and DNA were comparable in the HSK and non-HSK groups, Herpes may play an underestimated and as yet undefined role in nonherpetic and clinically atypical herpetic stromal keratitis, either as a primary trigger of the disease or as a secondary contributor to it. In this category of individuals, early antiherpetic therapy should be considered if patients do not respond in the expected manner to treatment for non-herpetic stromal keratitis.

\section{Introduction}

According to accepted concepts, recurrences of herpetic stromal disease are triggered by the reactivation of latent virus within the trigeminal ganglion or its periphery, this event being followed by transneuronal spread to the cornea $[11,26]$. Nevertheless, viral DNA has been detected within the cornea even when there exists no evidence of active or previous clinical disease [32]. The possibility of corneal viral latency $[9,28,33]$ and of persisting replicativity at various peripheral sites [34, 43], including the cornea [13], has added to the complexity of the picture without shedding further light on the disease mechanisms.

In cases of active stromal keratitis, replication has been localized to the corneal stroma by the direct electron-microscopic demonstration of complete viral particles therein [11]. It has been speculated that the presence of viral particles within the cornea triggers a specific local immune response which, in the initial phase, is directed against the virus itself [16, 38, 44]. At a later stage of the disease, and in chronic or recurrent inflam- 
mation, keratitis is more likely to result from an immunopathological process triggered by neutrophils and orchestrated by CD4-positive T-lymphocytes [25]. It remains a matter of debate whether a failing autoimmunoregulation underlies this process or whether the inflammatory activity is redirected in targeting as yet undefined cross-reactive but common antigenic epitopes of HSV-1 within stromal structures [3], thereby inducing a stromal autoreactive process $[40,45]$. By this means, the inflammatory process would become independent of viral replication.

In humans, primary ocular HSV-1 infection is not unusually subclinical [31], whereas the course followed by chronic and recurrent keratitis depends heavily upon the extent of stromal involvement, neovascularization and cicatrization [20].

Both amplification of HSV-1 DNA by polymerase chain reaction (PCR) and the immunohistochemical localization of viral antigens have proved to be sensitive means of detecting HSV-1 activity [21]. Accordingly, the aetiologic diagnosis of viral diseases such as necrotizing herpetic retinopathies may be established in up to $90 \%$ of cases by analysing samples of aqueous humour [14]. In instances of recurrent stromal keratitis, however, neither antigen detection nor the amplification of viral DNA by PCR has proved to be sufficiently sensitive [16, 19, 37]. The fact that even highly sensitive techniques have consistently failed to confirm the aetiology in cases of herpetic stromal keratitis may be accounted for by one of three hypotheses. It is possible, of course, that the clinical diagnosis is false. Alternatively, the replication of HSV-1 could lie below the level of detection. On the other hand, the low copy numbers of viral antigen and DNA could have been destroyed by local protease and DNAse activity. In this case, HSV-1 would play a subordinate role at the time of clinical diagnosis, but would nevertheless be capable of initiating a T-cell-directed immunopathological response even in the later absence of viral replication. This latter theory is currently gaining credence amongst virologists and immunologists in the field [33, 40].

We still have no clear conception of the manner in which HSV-1 drives herpetic keratitis. Viral replication probably takes place predominantly within the corneal epithelium, whilst the inflammatory reaction is expressed almost exclusively within the underlying stroma [40]. The enigma lies in the circumstance that viral repli- cation is a prerequisite for the induction of inflammation [2].

HSV-1 has been reported to be present within both inflamed and clinically healthy corneal tissue [32], thereby raising doubt as to the clinical relevance of its detection. In the present study, we attempted to define the role of HSV-1 in cases that were not clinically attributable to this virus or not unambiguously so. This category of individuals was referred to as the non-herpetic stromal keratitis (non-HSK) group. Findings relating to the detection rates of HSV-1 antigens and DNA in this non-HSK group were compared to those in individuals with either clinically typical herpetic stromal keratitis (HSK group; positive control) or non-inflammatory degenerative keratopathy (negative control).

\section{Materials and methods}

A total of 153 corneal buttons were obtained from patients undergoing keratoplasty. Of these, 51 had clinically typical HSK [group 1 (positive control): HSK] and 72 had stromal keratitis which was not clinically attributable to HSV-1 or not unambiguously so [group 2 (experimental): non-HSK]; the other 30 had non-inflammatory degenerative keratopathy [group 3 (negative control)]. Corneal buttons were included in groups 1 or 2 irrespective of the level of disease activity. Our justification for this is that viral antigens and/or DNA presumably persist in the cornea for a lifetime, thus rendering their detection independent of disease activity. This concept of long-term persistence and latency of viral antigens and DNA within corneal tissue has only recently been reinforced $[5,7,9,12,35]$. Until now, there has existed no evidence for an association between the detection rates of viral DNA and/or antigens and clinical disease activity. Nevertheless, the vast majority of patients in groups 1 and 2 did not manifest marked inflammatory activity at the time of corneal transplantation.

Experimental and control groups

Group 1 (positive control), HSK. The diagnosis of HSK was established if a systemic granulomatous disease condition had been ruled out anamnestically in individuals with four or more of the eight criteria listed in Table 1 . The anamnestic exclusion of systemic granulomatous disease was targeted to rule out ocular involvement in untreated or insufficiently treated cases of mycobacterial, sarcoidotic or syphilitic disease, which might lead independently to an unsatisfactory postoperative course.

Group 2 (experimental), non-HSK. The diagnosis of a non-herpetic disease condition was established in cases of stromal keratitis that did not meet the inclusion criteria for group 1, i.e. in patients whose clinical picture was not typically herpetic, and in those whose condition had been proved to be of other origin (Table 2).
Table 1 Diagnostic criteria for HSK
History of recurrent stromal keratitis

History, or documented episodes, of dendritic epithelial keratitis

Recurrent disciform keratitis with endothelial precipitates

Recurrent interstitial keratitis with deep stromal vascularization or acute stromal necrosis

Corneal hypaesthesia

Post-inflammatory sectorial atrophy of the iris after sectorial granulomatous iritis

Secondary glaucoma

Documented response to combined systemic Acyclovir and local steroid treatment in the past 
Table 2 Diagnostic criteria for non-HSK

Table 3 Diagnostic criteria for non-inflammatory degenerative keratopathy
Inflammatory corneal disease that fails to meet the criteria for herpetic keratitis, i.e.

Scar after interstitial or parenchymatous keratitis without recurrences

Keratitis in systemic rheumatic and autoimmune disease

Viral keratitis of proven non-herpetic (i.e. varicella-zoster) origin

Proven bacterial or mycotic keratitis without recurrence

Excluded: Scarring induced by trauma or chemical burns
Keratoconus

Simple or secondary endothelial atrophy

Corneal dystrophies (i.e. Fuchs' dystrophy)

Excluded: Scarring induced by trauma, chemical burns or unknown factors
Group 3 (negative control), degenerative keratopathy. Cases of established degenerative corneal disease with no clinical evidence of an active or previous corneal inflammatory episode (Table 3).

Since no generally accepted set of criteria exists for an unequivocal differentiation between each and every clinical entity, the distinguishing features summarized in Tables 1, 2 and 3 are based upon our own clinical experience. Accordingly, clinically typical cases of herpetic keratitis (group 1) are separated from the broad experimental category (group 2) embracing all other forms of inflammatory keratitis, including possibly atypical HSK, and from the negative control group, which includes all non-inflammatory forms of keratopathy (group 3). For a differentiation on this basis, all patients with corneal disease attributable to trauma, chemical burning or an unknown cause had to be excluded [15]

\section{Collection of corneal buttons}

Excised corneal buttons were tranisected through the scarred region, immediately fixed in buffered $4 \%$ formaldehyde solution for $24 \mathrm{~h}$ and then embedded in paraffin. Tissue sections $30 \mu \mathrm{m}$ thick were prepared and used for DNA extraction and amplification, as described in detail elsewhere [14]. Briefly, DNA was liberated by digesting the tissue in $100 \mu \mathrm{l}$ of proteinase $\mathrm{K}$ buffer for $30 \mathrm{~min}$ at $60^{\circ} \mathrm{C}$ and for $10 \mathrm{~min}$ at $95^{\circ} \mathrm{C}[13,18]$. After centrifugation, $5 \mu \mathrm{l}$ of the supernatant were withdrawn and either used immediately for the amplification assay or stored at $-20^{\circ} \mathrm{C}$ for future analysis.

From the second half of the scarred corneal button, an approximately $100-\mu \mathrm{g}$ sample was excised and incubated in $200 \mu \mathrm{l}$ of proteinase $\mathrm{K}$ buffer as described above. After centrifugation $(10,000 \mathrm{~g}$ for $10 \mathrm{~min}$ ), the supernatant was withdrawn and either used immediately for DNA amplification or stored at $-20^{\circ} \mathrm{C}$ for future analysis [13].

\section{Methods for the detection of HSV-1 DNA or antigens}

DNA amplification and hybridization. The amplification procedure has been fully described elsewhere [13]; only the pertinent details are given here. DNA amplification was run under standard conditions. Primers were directed against the glycoprotein D gene (amplification fragment length: 221 base pairs [1]) and the thymidine kinase gene (amplification fragment length: 110 base pairs [23]). Carryover was prevented by a pre-amplification cleavage with uracil $\mathrm{N}$-glycosylase [22] and by incorporating uracil triphosphates into the amplificates. All buffers and media used were routinely run as internal negative controls to exclude the possibility of viral contamination. Internal controls for specificity included culture supernatants from cells infected with HSV-1, HSV-2, varicella-zoster virus or cytomegalovirus. In each amplification experiment, positive internal controls containing $10 \mathrm{ng}$ of an HSV-1 DNA equivalent, consisting of approximately 10 viral copies (fragment length: 221 base pairs), were also included. Each positive result was confirmed by an independent control amplification. Negative samples were sporadically spiked with minute amounts of control HSV-1 DNA and run in separate PCRs to detect false negatives attributable to the presence of inhibitory factors. A tissue was deemed to harbour HSV-1 DNA if this was amplified from one of the two samples of fresh or paraffinized tissue.

Immunohistochemistry. Sections of paraffin-embedded corneal tissue $6 \mu \mathrm{m}$ thick were transferred to SuperFrost slides (Wetzel Glasses, Mainz, Germany), dewaxed and rehydrated. They were then incubated at ambient temperature with primary rabbit-antiHSV-1 (B 0114, DAKO Diagnostics Ltd., Cambridgeshire, UK; diluted 1:200 in Tris-chloride buffer, $\mathrm{pH}$ 7.2), the antibody then being detected according to the streptavidin/biotin method (in compliance with the manufacturer's instructions; LSAB-2 kit, DAKO Diagnostics, Cambridgeshire, UK).

Positive and negative internal controls consisted of a pair of donor corneas that failed to meet our transplantation criteria. One of the corneas, maintained in minimal essential medium, served as the negative control, whilst its partner, infected in vitro with a clinical HSV-1 isolate, served as the positive control. These controls were always run in parallel so as to be able to define the signal/noise amplitude. The evaluation was conducted according to a standard protocol, the investigator being kept in ignorance of information pertaining to patients. To assess specificity, we also evaluated the distribution and cell-association of positive signals In the event of high background staining or the inability to interpret a given result, a second experiment was run using a higher dilution of the antibody (1:1000 instead of 1:200).

\section{Statistical analysis}

Data were analysed using the "Statistica for Windows" program, version 5.1 (StatSoft, Inc., Tulsa, Okla., USA), the $\chi^{2}$ test being employed for comparisons between two groups and the maximumlikelihood $\chi^{2}$ test for those involving all three. Statistical significance was set at a $p$ value of $<0.05$.

\section{Results}

Immunohistological staining of corneal explant tissue revealed the presence of HSV-1 antigens in $8(11 \%)$ of the 72 buttons excised from patients with non-HSK, in 16 $(31 \%)$ of the 51 buttons derived from individuals with HSK ( $\chi^{2}$ test: $\left.p=0.01\right)$, and in $1(3 \%)$ of the 30 taken from subjects with non-inflammatory degenerative kera- 
Table 4 Analysis of corneal explant buttons

${ }^{*} p=0.01$ (HSK vs non-HSK vs degenerative keratopathy)

\begin{tabular}{llcll}
\hline Detection of & $\begin{array}{l}\text { HSK } \\
(n=51)\end{array}$ & $\begin{array}{l}\text { Non-HSK } \\
(n=72)\end{array}$ & $\begin{array}{l}p \text { value HSK/ } \\
\text { non-HSK }\end{array}$ & $\begin{array}{l}\text { Degenerative keratopathy } \\
(n=30)\end{array}$ \\
\hline Antigen $(\mathrm{Ag})$ & $16 / 51(31 \%)$ & $8 / 72(11 \%)$ & 0.01 & $1 / 30(3 \%)$ \\
DNA & $11 / 51(22 \%)$ & $16 / 72(22 \%)$ & 0.97 & $1 / 30(3 \%)$ \\
Ag and DNA & $8 / 51(16 \%)$ & $6 / 72(8 \%)$ & 0.32 & $1 / 30(3 \%)$ \\
Ag and/or DNA* & $19 / 51(37 \%)$ & $18 / 72(25 \%)$ & 0.20 & $2 / 30(7 \%)$ \\
\hline
\end{tabular}

topathy. The analysis for HSV-1 DNA yielded corresponding numbers of $16 / 72(22 \%), 11 / 51$ (22\%; $\chi^{2}$ test: $p=0.97)$ and $1 / 30\left(3 \% ; \chi^{2}\right.$ test: $\left.p=0.06\right)$.

Taking these findings together, HSV-1 antigens and or DNA were detected in $18(25 \%)$ of the 72 buttons excised from patients with non-HSK, in 19 (37\%) of the 51 buttons derived from individuals with HSK $\left(\chi^{2}\right.$ test: $p=0.20)$, and in $2(7 \%)$ of the 30 buttons taken from subjects with non-inflammatory degenerative keratopathy ( $\chi^{2}$ test: $\left.p=0.01\right)$ (Table 4$)$.

\section{Discussion}

In this study, we evaluated corneal explant tissue immunohistochemically for the presence of HSV-1 antigens (against glycoprotein D) and for that of HSV-1 DNA by amplification and hybridization. By these means, we attempted to define the role of HSV-1 in the pathogenesis of non-HSK at the time of corneal transplantation.

Clinical signs and symptoms represent the sole established basis for diagnosing HSK, which, for some elusive reason, cannot be confirmed by laboratory testing in the majority of cases, despite important therapeutic consequences. Although the clinical signs and symptoms are deemed to be characteristic (Table 1), our data indicate that they are unable to differentiate clearly between HSK and non-HSK at the time of corneal transplantation. There exists a substantial body of evidence indicating that many cases of HSK are either overlooked or diagnosed late, which is a disquieting circumstance. In concrete terms, the fact that HSV-1 was detected in only $37 \%$ of the samples derived from patients with active HSK implies that the detection sensitivity was likewise $37 \%$. On this basis, the $25 \%$ detection level revealed for the non-HSK group represents an underestimation of the HSV-1 contribution, the truer value lying around $60 \%$.

It should also be borne in mind that the majority of patients had undergone long-term, multidrug anti-inflammatory treatment for previous and current disease states prior to corneal surgery. This circumstance will inevitably modify the clinical as well as the histological picture of the disease and might thereby influence the interpretation of the clinical situation and reduce the predictive value of the immunohistochemical evaluation. Indeed, the immunohistochemical analysis confirmed the pres- ence of HSV-1 in less than one third of the cases with HSK. In tissue evincing little to moderate inflammation, the HSV-1 antigen is readily detected, but when chronic stromal infiltration and vascularization are manifest, the signal is often masked by intense non-specific background straining. Although the severe inflammatory reaction may be partially attributable to previous treatment, the immunohistochemical mapping of HSV-1 is nonetheless known to yield highly variable results [2, 16].

In cases of active herpetic uveitis and keratouveitis, our own aqueous humour analyses have led us to the realization that antigen degradation (possibly by mononuclear cells $[10,30]$ ) or neutralization is responsible for a marked attenuation in detection sensitivity with increasing time after the onset of inflammation [37]. The existence of such a relationship has been demonstrated experimentally [2], but not in a clinical setting. HSV-1 DNA is known to be more resistant to enzymatic degradation than HSV-1 antigens in the corneal environment [2], which explains the twofold higher detection rate for HSV-1 DNA.

Although a positive amplification signal proves the local presence of HSV-1, it does not necessarily follow that the virus contributes to the clinical disease [29]. Added to this uncertainty, we have no conception of how the presence of viral DNA in clinically healthy corneal tissue $[5,8,14,27,32]$ is to be understood. The possibility of contamination has, of course, to be considered. But several independent laboratories, each with a long-standing reputation in DNA amplification, and each taking the utmost precautions to prevent the carryover of amplification products, have obtained identical results in this respect $[6,14,24,42]$. We are thus forced to conclude that the presence of HSV-1 DNA in the human cornea may be harmless or even physiological. However, the mechanism underlying its tolerance, as well as its possible physiological function, have yet to be defined, and the possibility of its playing a hazardous role after the transplantation of infected corneal tissue also remains to be clarified $[5,36,41]$.

In conclusion, a high proportion of cases with nonherpetic or clinically atypical stromal keratitis (non-HSK group) harboured HSV-1 antigens or DNA, the clinical relevance of which remains to be clarified. On the other hand, the applied case-definition criteria for HSK, although generally acceptable, are perhaps too stringent, in 
that a substantial number of individuals with ambiguous clinical signs and symptoms are excluded and assigned to the non-HSK group. Therefore in cases of non-HSK which do not respond in the expected manner to treatment for a non-herpetic condition, it may be expedient to instigate supplementary anti-herpetic and immunomodulatory therapy.

Acknowledgement This study was partially supported by a grant from the Swiss National Science Foundation (no. 32-39730.93) to J. Garweg.

\section{References}

1. Aurelius E, Johannson B, Sköldenberg B, Staland A, Forsgren M (1991) Rapid diagnosis of herpes simplex encephalitis by nested polymerase chain reaction assay of cerebrospinal fluid. Lancet 337:189-192

2. Babu JS, Thomas J, Kanangat S, Morrison LA, Knipe DM, Rouse BT (1996) Viral replication is required for induction of ocular immunopatholoy by herpes simplex virus. J Virol 70:101-107

3. Banks TA, Rouse BT (1992) Herpes viruses-immune escape artists? Clin Infect Dis 14:933-941

4. Biswas S, Suresh P, Bonshek RE, Corbitt G, Tullo AB, Ridgeway AE (2000) Graft failure in human donor corneas due to transmission of herpes simplex virus. $\mathrm{Br} \mathrm{J}$ Ophthalmol 84:701-705

5. Cantin EM, Chance J, McNeal J, Willey DE, Openshaw H (1991) Detection of herpes simplex virus DNA sequences in corneal transplant recipients by polymerase chain reaction assays. Curr Eye Res 10 [Suppl]:5-21

6. Cleator GM, Klaper PE, Dennett C, Sullivan AL, Bonshek RE, Marcyniuk B, Tullo AB (1994) Corneal donor infection by herpes simplex virus: herpes simplex virus DNA in donor corneas. Cornea 13:294-304

7. Cook SD, Brown SM (1986) Herpes simplex virus type I persistence and latency in cultured rabbit corneal epithelial cells, keratocytes, and endothelial cells. Br J Ophthalmol 70:642-650

8. Cook SD, Hill JH (1991) Herpes simplex virus: molecular biology and the possibility of corneal latecy. Surv Opthalmol 36:140-148

9. Crouse CA, Pflugfeder SC, Pereira I, Cleary T, Rabinowitz S, Atherton SS (1990) Detection of herpes virus genomes in normal and disease corneal epithelium. Curr Eye Res 9:569-581

10. Cunningham AL, Turner RR, Miller AC, Para MF, Merigan TC (1985) Evolution of recurrent herpes simplex lesions. An immunohistologic study. J Clin Invest 75:226-229
11. Dawson C, Togni B, Moore TE (1968) Structural changes in chronic herpetic keratitis. Arch Ophthalmol 79:740-747

12. Gamus D, Romano A (1988) Herpetic imprint and privileged areas of its target organ: local latency and reactivation in herpetic keratitis. Ped Syst Ophthalmol 11:37-40

13. Garweg JG, Böhnke M (1996) Slow viral replication of HSV-1 is responsible for early recurrence of herpetic keratitis after corneal grafting. Graefes Arch Clin Exp Ophthalmol 234 [Suppl]: 133-138

14. Garweg G, Böhnke M (1997) Varicellazoster virus is strongly associated with atypical necrotizing herpetic retinopathy. Clin Infect Dis 24:603-608

15. Halberstadt M, Machens M, Gahlenbek K-A, Böhnke M, Garweg JG (2002) The outcome of corneal grafting in patients with stromal keratitis of herpetic and nonherpetic origin. Br J Ophthalmol 86:646-652

16. Holbach LM, Font RL, Bear W, Tittler SJ (1991) HSV-antigens and HSVDNA in avascular and vascularized lesions of human herpes simplex keratitis. Curr Eye Res 10 [Suppl]: 63-68

17. Karupiah G, Xie Q, Buller RM, Nathan C, Duarte C, MacMicking JD (1993) Inhibition of viral replication by interferon-induced nitric oxide synthase. Science 261:1445-1448

18. Kawasaki I (1990) Sample preparation from blood, cells, and other fluids. In: Innis MA, Gelfand DH, Sninsky JJ, White TJ (eds) PCR protocols. Academic Press, San Diego, pp 146-152

19. Kaye SB, Baker K, Bonshek R, Maseruka H, Grinfield E, Tullo AB Easty DL, Hart CA (2000) Human herpesviruses in the cornea. $\mathrm{Br} \mathrm{J}$ Ophthalmol 84:563-571

20. Keadle TL, Usui N, Laycock KA, Miller JK, Pepose JS, Stuart PM (2000) Il- 1 and TNF- $\alpha$ are important factors in the pathogenesis of murine recurrent herpetic stromal keratitis. Invest Ophthalmol Vis Sci 41:96-102

21. Kowalski RP, Gordon YJ, Romanowski EG, Araullo-Cruz T, Kinchington PR (1993) A comparison of enzyme immunoassay and polymerase chain reaction with the clinical examination for diagnosing ocular herpetic disease. Ophthalmology 100:530-533
22. Longo MC, Berninger MS, Hartley JL (1990). Use of uracil DNA glycosylase to control carry-over contamination in polymerase chain reactions. Gene 93:125-128

23. Lynas C, Cook SD, Laycock KA, Bradfield JW, Maitland NJ (1989) Detection of latent virus mRNA in tissue using the polymerase chain reaction. J Pathol 157:285-289

24. Morris DJ, Cleator GM, Klapper PE, Cooper RJ, Biney EO, Dennett C, Marcyniuk B, Tullo AB (1996) Detection of herpes simplex virus DNA in donor cornea culture medium by polymerase chain reaction. $\mathrm{Br} \mathbf{J}$ Ophthalmol 80:654-657

25. Nash AA, Jayaswiya A, Phelan J, Cobbold SP, Waldmann H, Prospero T (1987) Different roles of L3T4+ und Lyt2+ T cell subsets in the control of an acute herpes simplex virus infection of the skin and nervous system. J Gen Virol 68:825-833

26. Nicholls SM, Shimeld C, Easty DL, Hill TJ (1996) Recurrent herpes simplex after corneal transplantation in rats. Invest Ophthalmol Vis Sci 37:425-435

27. Openshaw HJ, McNeill I, Lin XH, Niland J, Cantin EM (1995) Herpes simplex virus DNA in normal corneas: persistence without viral shedding from ganglia. J Med Virol 46:75-80

28. Pavan-Langston D, Rong BL, Dunkel EC (1989) Extraneuronal herpetic latency: animal and human corneal studies. Acta Ophthalmol 67 [Suppl]: 135-141

29. Pendergast SD, Werner J, Drevon A, Wiedbrauk DL (2000) Absence of herpesvirus DNA by polymerase chain reaction in ocular fluids obtained from immunocompetent patients. Retina 20:389-393

30. Pepose JS (1991) Herpes simplex keratitis: role of viral infection versus immune response. Surv Ophthalmol $35: 345-352$ 
31. Pepose JS, Leib DA, Stuart PM, Easty EL (1996) Herpes simplex virus: anterior segment of the eye. In: Pepose J, Holland GN, Wilhelmus KR (eds) Ocular infection and immunity. Mosby, St. Louis, pp 905-932

32. Rong BL, Pavan-Langston D, Wenig QP, Martinez R, Cherry JM, Dunkel EC (1991) Detection of herpes simplex thymidine kinase and latency-associated transcript gene sequences in human herpetic corneas by polymerase chain reaction amplification. Invest Ophthalmol Vis Sci 32:1808-1815

33. Rouse BT, Kannangat S (1999) Herpes simplex virus. In: Ahmed R, Chen J (eds) Persistent viral infections, 1st edn. Wiley, New York, pp 165-182

34. Rustigian R, Smulow JB, Tye R (1966) Studies of latent infection of skin and oral mucosa in individuals with recurrent herpes simplex. J Invest Dermatol 47:218-221
35. Sabbaga EM, Pavan-Langston D, Bean KM, Dunkel EC (1988) Detection of HSV nucleic acid sequences in the cornea during acute and latent ocular disease. Exp Eye Res 47:545-553

36. Sengler U, Spelsberg H, Reinhard T, Sundmacher R, Adams O,

Auw-Haedrich C, Witschel H (1999) Herpes simplex virus (HSV-1) infection in a donor cornea (letter). Br J Ophthalmol 83:1405

37. Schacher S, Garweg JG, Russ CE, Böhnke M (1998) Die Diagnostik der herpetischen Uveitis und Keratouveitis. Klin Monatsbl Augenheilkd 212:359-362

38. Smith PM, Wolcott RM, Chervenak R, Jennings SR (1994) Control of acute cutaneous herpes simplex virus infection: T-cell mediated viral clearence is dependent upon interferon- $\gamma($ IFN- $\gamma)$. Virology 202:76-88

39. Streilein JW, Dana MR, Ksander BR (1997) Immunity causing blindness: five different paths to herpes stromal keratitis. Immunol Today 18:443-449

40. Thomas J, Rouse BT (1997) Immunopathogenesis of herpetic ocular disease. Immunol Res 16:375-384
41. Tullo AB, Marcyniuk B, Bonshek R, Dennett C, Cleator GM, Lewis AG, Klapper PE (1990) Herpes virus in a corneal donor. Eye 4:766-767

42. van Gelderen BE, van der Lelij A, Treffers WF, van der Gaag R (2000) Detection of herpes simplex virus type 1,2 and varicella zoster virus DNA in recipient corneal buttons. Br J Ophthalmol 84:1238-1243

43. Wald A, Zeh J, Selke S, Ashley RL, Corey L (1995) Virologic characteristics of subclinical and symptomatic genital herpes infections. N Engl J Med 333:770-775

44. Wildy P, Gell PG (1985) The host response to herpes simplex virus. Br Med Bull 41:86-91

45. Zhao ZS, Granucci F, Yeh L, Schaffer PA, Cantor H (1998) Molecular mimicry by Herpes simplex virus type-1: autoimmune disease after viral infection. Science 279:1344-1347 